\title{
Modern Democracy-Welfare State and Public Goods. A current consequence for Greece.
}

EmmanouilMavrozacharakis, $\mathrm{PhD}$ Candidate, Department of Political Science, University of Crete, Researcher of the Centre for Human Rights (KEADIK)

Abstract

People expect the state to create jobs and provide them with a social security net. Whatever its defects, whatever the virtues of the private sector, no structure other than the state can today provide citizens with the basic public goods. Under the present right-wing government of Nea Dimokratia in Greece, which is not particularly at odds with neoliberalism, a very active role of the state is not expected. Also is nor expected the introduction of a serious program of public investment and demandboosting to stimulate the national economy and enter into a virtuous circle of recovery. Greece, which has undergone the economic crisis with drastic cuts in its traditionally deficient social state, has to respond directly to the marked underinvestment in public goods (in key areas such as education, health, natural disasters, dealing with decent living conditions).The most important tool for inputting resources is the tax system. 
The prevalence of the ideas of enlightenment and of the rational spirit undoubtedly complies with the perception that economic, social and political crises are not created by nature or god but by collective human choices and decisions (Shruti:2017,1-2). The same goes for overtaking them. We can therefore only regard the current right-wing governance in Greece as a result of a collective choice. At first sight, this choice was indeed rational in the sense that in the electorate invests in the hope of an orderly state through the balancing of social development, the promotion of an intact economy. In this sense, the people felt that the right-wing could relieve the business of unnecessary state interference or bureaucracy, without the state abandoning its guaranty and regulatory role. From the above to a certain extent, the new right-wing government in Greece has taken up recently his legitimation of power. In the past, this legitimation has been broken because the right-wing rule was not accompanied by the constitution of an orderly state, as the right-wing party had been evangelized. Claus Offe $(1997,81)$ : underlines that «all societies, in order to reproduce themselves in a manner compatible with the notion of "social order", must solve two reciprocal core problems in institutionalized ways. First, they must allocate (adult) human labor power to valued ("productive") functions, thereby situating "people" into "places".

The set of allocation rules through which this task is performed includes selective exemptions from the expectation to perform economically valued activities that apply, in our society, to the young, the old, the sick, and the independently wealthy. Putting people in places is a process that results in patterns of (however unequal) inclusion, participation, recognition, self-respect, and discipline, as well as an overall pattern of division of labor. It provides people with relatively stable expectations as to where they belong and what conduct is appropriate in work and in life. Second, societies must provide people, in equally patterned and routinized ways, with the means of livelihood in return for the valued functions they perform (or have performed at earlier points) and as a precondition of the continued performance of these functions. These means include income (or the claim to means of the consumption of "goods") and protection (or the, at least partial, compensation of risks, or the incidence of "bads").

These two problems - the problem of production and the problem of distribution - can be institutionally solved in a myriad of ways». With other words, 
the mission of the state governed by the rule of law "is not limited only to the care and planning of adequate infrastructure in the road and transport network, but also to the education of all young people, to the health of citizens, to the employment of all those who seek work, the quality of the environment and culture (Johnston:2002, 1). Moreover, this is in line with the idea of citizenship established after the World War II by TH Marschall and J M Keynes and linked to the welfare state and the pursuit of political, economic and social equality and cultural autonomy (van Sternbergen:1994, $1-10)$.

As Dahrendorf $(1994,13)$ states «Marshall defines citizenship as the body of rights and duties - the status - which goes with full membership of a society. This status is by definition removed from the vagaries of the market. Citizenship is a noneconomic concept. It defines people's standing Independent of $t$ e relative value attached to their contribution to the economic process. The elements of citizenship are thus unconditional. This is as true for obligations as it is for rights. The right to vote, for example, is not dependent on paying taxes, although paying taxes is an obligation associated with the status of citizenship». The idea of democracy was therefore linked to the demand for more social justice and the creation of public services related to education, health, housing, urban regeneration, public transport, subsidized culture, and the arts.

Habermas (1994, 25) notes that « today, however, the expression 'Staatsburgerschaft' or 'citizenship' is not only used to denote membership of a state, but also for a status defined by civil rights ..... The status of citizen is constituted above all by those democratic rights which the individual can reflexively lay claim to in order to alter his or her material legal status». The rights therefore in a modern democracy far outweigh the sphere of the free economy or political participation and include social participation and distributive justice Lamont:2017).

Together with the individual rights of freedom and the rights to freedom of expression and ideas, social rights form a framework that aims to live the life of a civilized being as opposed to state patronage and discrimination (Beetham:1998, 2129). In other words, only through the revival of the democratic ideal and the establishment of the rule of law of modern times, public social space was established which guaranteed wider production of public goods and services, the mediation and harmonization of interests, the regulation and exercise of individual and social rights.( Dewey: 1937, 457-67). Through democracy in the end, the individual becomes a 
citizen and a person. However, investment in the citizen, namely in quality public goods and social services such as education, health - care, social cohesion is what is needed to sustain a society the pressures of international competition and to respond to international challenges.

The welfare state and its functions are not only concessions to the citizens, but necessary conditions for the survival of a capitalist society. " (Midgley: 1997, 105106). The issue of Democracy is therefore directly linked to the issue of social cohesion (Cuellar:2009), which many governments, being a victim of the syndrome of international competitiveness and neoliberal ideology, often overlook (Fougner: 2006).

As Krugman $(2004,44)$ )among others points out, governments should not fall victim to an Obsession of "competitiveness" because it is dangerous and can lead to mistaken choices. The idea that a country's economic progress is solely dependent on its success on the global market is an unreliable case based on empirical analysis. Krugman $(2004,42)$ notes that «Most of those who have preached the doctrine of competitiveness have not heen old-fashioned protectionists. They want their countries to win the global trade game, not drop out. But what if, despite its best efforts, a country does not seem to he winning, or lacks confidence that it can? Then the competitive diagnosis inevitably suggests that to close the borders is better than to risk having foreigners take away high-wage jobs and high-value sectors. At the very least, the focus on the supposedly competitive nature of international economic relations greases the rails for those who want confrontational if not frankly protectionist policies».

Moreover, the legitimacy of the state does not depend on whether it can manage globalization, but on how effective it is to deliver public goods to its own nationals, at least with other entities, in a context naturally shaped by globalization. In a further sense «The promotion of a higher quality of life and the protection of human dignity should be regarded as a crucial element in any effort to globalize. Accordingly, globalization cannot mean the abandonment of all things to market forces. In other words, "the economic sphere cannot be separated from the more complex fabric of social and political life and sent shooting off on its own trajectory. To survive and thrive, a global economy must have a more solid foundation in shared values and institutional practice. It must advance broader and more inclusive social purposes.Basic needs must be satisfied as an end in itself, but also as a means to allow 
people to be able to seize to a greater extent the benefits of globalization..... Public sector capacity-building in terms of institutions, human resources, mobilization, and management of resources, as well as innovation and information technology, is crucial in ensuring that countries are able to seize the opportunities of globalization. There is a growing need to strengthen national capacity to design and implement people-centered programs and policies; to strengthen national capacity to ensure that countries benefit from globalization, while minimizing its costs; to enhance citizen participation at all levels of governance and to foster partnerships between the State, civil society and the private sector for development» (Bertucci-Alberti:2001, 25-26). People expect the state to create jobs and provide them with a social security net. Whatever its defects, whatever the virtues of the private sector, no structure other than the state can today provide citizens with the basic public goods.

Sen notes that : "what people can positively achieve is influenced by economic opportunities, political liberties, social powers, and the enabling conditions of good health, basic education, and the encouragement and cultivation of initiatives» (Sen: 1999,. 5)The State has a very important role to play in this respect. Under the present right-wing government of Nea Dimokratia in Greece, which is not particularly at odds with neoliberalism, a very active role of the state is not expected. Also is nor expected the introduction of a serious program of public investment and demand-boosting to stimulate the national economy and enter into a virtuous circle of recovery. It is clear that the right-wing in Greece remains locked up in the anachronistic undertaking of neoliberalism and does not follow the example of a modern European center-right like German CDU that turned to the values of social justice, putting forward policies that combined economic growth, social cohesion, orderliness.

As a result, there was a clear political stigma, the widening of social alliances and finally systematic sweeping victories of the European center-right. This explains why in countries like Germany, the first socio-economic effects of the crisis (redundancies, unemployment eruptions, falling purchasing power) are not particularly acute and did not lead to a more radical electoral behavior and instead created the paradox that the neoliberal right-wing factions which launched with their antisocial policies the attack on social acquisitions were strengthened as well as the far-right regimes that played elaborately with the issue of security and immigration. While one would expect, due to the crisis, the strengthening of anti-capitalist tendencies and ideas, it was at least apparently the opposite. The modern center-right, 
in many cases, adopted the Keynesian logic of strengthening demand through public spending and government interventions.

However, in order for a public spending strategy to be successful, it must be designed on the basis of the social entity (social benefit) and the costs involved (social costs). Public goods resulting from the corresponding public expenditure are usually produced by public bodies (eg national defense, internal security). Similarly, in Greece, most of the public goods, for which there is a need for intervention by public bodies for their provision, are produced by their own public bodies and are provided free of charge to the people of the community. Their cost is covered by income taxation. According to economic theory, Public goods, have the special feature that the user who enjoys them can not prevent other users from enjoying them at the same time, according to the principles of indivisibility and publicness (Rawls:2003,235). Clean air is a public good that is not guaranteed only for half the inhabitants of a region (taxpayers or those who do not pollute). Air quality is common to all. Public order and the protection of the life and property of citizens was the predominantly public goods ( Janda/ Berry/, Goldman: 2009, 9). It is common ground that this is an area in which private initiative alone is not enough. We would say that security, more than education and health, is the main reason why people have, and still Tolerate, states (Groc:2016, 10-12).

A relatively balanced policy within a modern state aims primarily to ensure:

1. The optimal distribution of available productive factors (labor, capital, buildings, land and so on) between different users to ensure sufficient production of goods and services that will meet the needs of the population over time

2. Excellent distribution of national income (total country production in one year, measurable in value, ie in euros) according to the prevailing perceptions of social justice in order to prevent social unrest. With Marxist terminology, one would say that the mitigation of class contradictions through the closing of the income gap is a precondition for social peace. The distribution is through tax deduction of income from them with and through pensions or benefits that add income to non-residents. A critical dimension is the ability to pursue a social policy that in some cases serves (the social democratic model) to lift inequality, but in other cases (liberal model) the maximum requirement is to provide a safety net to alleviate extreme poverty. In the 
countries of mainland Europe where social protection is almost identical to social security (as in Greece), the main objective is to promote social cohesion - a goal incompatible with a rapid deterioration of inequality, but not necessarily with the keeping it at a stable and perhaps relatively high level

3. Steady, balanced and long - term growth combined with pursuing full employment and the achievement of price stability. Combined policies attempt to achieve the economic well-being of the people and their dignified survival, but at least to meet their basic needs above the poverty line. It is obvious and understandable that, depending on the political and ideological nature of each government, its priorities, its capabilities and the culture of every people, the center of gravity will be placed in one of the three basic objectives of every modern state.

A state with strong feelings of law and social equality will mainly seek to ensure excellent distribution of national income and stabilization of prices. A state that holds liberal views (in the good sense ...) will seek to make the most of the factors of production and promote growth, without generating major failures in social cohesion. A neo-liberal government, on the other hand, will turn its interest in a democracy that is synonymous with the free market, while issues of equality, social justice will be of secondary importance and used to reduce those who are subjected to social exclusion and punishment by the system itself (eg charities).

Despite the logical consistency of these differences, some analysts point to the objection that "Governments across the globe, from liberal to socio-democratic, are pushing policies that transfer wealth from many to few and shape the conditions for the birth of ruined societies are squeezed out of poverty, unemployment, social hardship and dissatisfaction, crime and the brutality of the police. For many years, reports of super-governmental institutions such as Social Watch, UNICEF and the United Nations Development Program have attempted to draw attention to the worsening socio-economic conditions around the world. Internationally recognized personalities from the economy, such as Joseph Stiglitz and Paul Krugman, denounce the anti-democratic and immoral agenda of the neoliberal elite. " With the economic crisis of 2007, however, the dividing lines between right and left again became distinct. Modernizing social democracy, following the Third Way model, has in many cases implemented extreme neoliberalist prescriptions, and has abandoned the social 
state as its basic ideological prowess, instead of stifling social inequalities. It then lost the traditional social strata that historically supported it, eventually falling into a deep identity crisis. It followed in many cases the election shrinking. It is obvious that due to the international economic crisis, the post-industrial social-democrat recipes have recurred their timeliness and charm.

The fundamental distinction between right and left is, therefore, re-emerging as a dilemma between the market and society. However, it follows from can only keep pace with social equality when there is democratic control only when there is a democracy. This is a qualitative differentiation in relation to the political philosophy of modernizing social democracy which has been of prime importance in development. Of course, we must look at solutions that are both visionary and workable. "At the level of implementation, the most effective answer was the Keynesian Revolution in the 1950s and 1960s, which confirmed the full compatibility between a market economy and social cohesion, provided that the state faces the really big flaw of the former: the structural the trend towards insufficient demand.

The undisputable substantial success of Keynesian macroeconomic policies supporting public demand depended, however, on two fundamental conditions: the economic sovereignty of the nation-state within its boundaries, and the explicit or silent agreement between entrepreneurs and workers to redistribute the profits resulting from the increase productive income (so-called income policy) '. Of course, the state today has greater difficulty in defining economic policy autonomously than in 20 or 30 years ago. The proliferation of financial instruments has created what some call "shadow worlds" - shadowy in the sense that they escape the control of the bodies assigned to them to manage economic policy. There is, therefore, a very level issue of democracy.

The new government of Nea Dimokratia which is now an irreversible event, should carefully and cautiously manage the actors of the traditional form of interest mediation (strong interests, economic and political oligarchies, guilds, unions, clerks, etc.) who often offer specialized integration of their interests into the system, in order to gain access to the core of the political system. Greece, which has undergone the economic crisis with drastic cuts in its traditionally deficient social state, has to respond directly to the marked underinvestment in public goods (in key areas such as education, health, natural disasters, dealing with decent living conditions ). The most important tool for inputting resources for the policy is the tax system. 


\section{References:}

Beetham, D (1998): Democracy: Key Principles, Institutions and Problems . In: Inter-Parliamentary Union (Ed) Democracy: Its Principles and Achievement. InterParliamentary Union, Geneva

Bertucci, G/ Alberti, A (2001) :Globalization and the Role of the State: Challenges and Perspectives United Nations Online Network in Public Administration and Finance

\section{http://unpan1.un.org/intradoc/groups/public/documents/un/unpan006225.pdf}

Cuellar, R (2009) : Social Cohesion and Democracy. International Institute for Democracy and Electoral Assistance, Stockholm

Dahrendorf; R (1994) : The changing Quality of Citizenship . In: In Van Sternbergen, B (Ed): The Condition of Citizenship. London, Thousand Oaks, New Delhi :Sage Puplikations , pp. 10-20

Dewey, J (1937): "Democracy and Educational Administration," School and Society 45 (April 3) ; 457-67.

Fougner, T (2006): The state, international competitiveness and neoliberal globalisation: is there a future beyond 'the competition state'? Review of International Studies , 32, 165-185

Groc, F (2016) :The Principle of Security . Polis Publishing. :Athens (in Greek)

Habermas, J (1994): Citizenship and national Identity . : In Van Sternbergen, B (Ed): The Condition of Citizenship. London, Thousand Oaks , New Delhi :Sage Puplikations, pp .20-35

Janda,K / Berry,J/ Goldman, J (2009):The Challenge of Democracy: American Government in a Global World, Texas Edition, Wadsworth, Boston

Johnston, M (2002): Good governance: rule of law, transparency, and accountability Available at: https://www.researchgate.net/publication/267974525_Good_Governance_Rule_of_La w_Transparency_and_Accountability 
Krugman, P (2004): Competitiveness: A Dangerous Obsession. In: Foreign Affairs Volume 73 , Nr. 2, pp. 28-44

Lamont, J (2017): Distributive Justice

https://plato.stanford.edu/entries/justice-distributive/

Midgley, J (1997): Social Welfare in Global Context. Sage

Thousand Oaks, London, New Delhi

Offe, C (1997): Towards a new Equilibrium of citizens rights and economic resources ?. In: OECD (Ed.) Societal Cohesion and the Globalising economy . What does the Future hold? Paris. pp. $81-108$

Rawls, J (2003): A Theory of Justice. Cambridge, Belknap Press of Harvard University Press Sen, A (1999): Development as Freedom, A.A. Knopf, New York

Shruti S (2017): The Rise of Citizenship and Rights Post the Advent of Enlightenment. J Pol Sci Pub Aff 5: 283. doi: 10.4172/2332-0761.1000283

Van Sternbergen, B (1994) : The Condition of Citizenship: an Introduction . In Van Sternbergen, B (Ed): The Condition of Citizenship. London , Thousand Oaks, New Delhi :Sage Puplications, pp. 1-10 